\title{
Structural style and evolution of a Late Triassic rift basin in the Central High Atlas, Morocco: controls on sediment deposition
}

\author{
CATHERINE BAUDON*, IVAN FABUEL-PEREZ and JONATHAN REDFERN* \\ North Africa Research Group, School of Earth, Atmospheric and Environmental Sciences, The University of \\ Manchester, Oxford Road, Williamson Building, Manchester M13 9PL, UK
}

\begin{abstract}
Late Triassic continental sediments deposited in an active-rift setting are exposed in the Oukaimeden-Ourika Valley, located in the Central High Atlas Basin of Morocco. The Oukaimeden Sandstone Formation is dominated by ephemeral and perennial braided fluvial facies, and is an outcrop analogue for Triassic sandstone hydrocarbon reservoirs found in Atlantic margin and North African basins. This paper documents detailed analysis of the outcrop data to investigate the influence of tectonics on deposition and the interplay with climatic controls. The geodynamic evolution of the basin is interpreted to be influenced by Atlantic rifting to the west and the formation of the Tethys Sea to the north, which led to the development of ENE and NNE striking normal faults. The present-day fault and outcrop geometry reflects later inversion due to the Alpine compression that led to uplift of the High Atlas and subsequent erosion.

The ENE trending rift-basin is bound by normal faults, which are probably in part reactivated older Hercynian structures. The facies distribution was controlled by a complex interplay of tectonic and climatic controls. Evidence for syn-sedimentary movement of both fault sets is observed, with stratigraphic thickening and associated progressive change in bedding dip. These faults controlled the basin dimension, geometry of the half-graben and created the accommodation for sediment deposition. The presence of breccia deposits close to the main ENE bounding faults indicates footwall erosion and deposition of basin margin fans. The location and orientation of the main fluvial system was controlled by these structures, and the main channel belts ran parallel and proximal to the controlling faults, whereas away from the main syn-depositional faults overbank deposits dominate. Smaller contemporaneous NNE oriented faults are generally shorter with less throw, and had only a limited influence on gross sedimentation patterns. These faults are interpreted to be syn-sedimentary, displaying characteristics that suggest basal detachment within the Triassic, and as such provide evidence for the extension direction during late Triassic time. A periodic change from ephemeral to perennial systems, with associated changes in architectural style, is potentially attributed to climatic control, although a structural influence cannot be dismissed. Copyright (C) 2009 John Wiley \& Sons, Ltd.
\end{abstract}

Received 11 May 2009; accepted 2 October 2009

KEY WORDS structural evolution; climatic influence; Late Triassic; fluvial sandstone; Morocco

\section{INTRODUCTION}

Two fundamental controls on the stratigraphic architecture and facies of syn-rift deposits are fault evolution (Cowie et al. 2000; Leppard and Gawthorpe 2006) and climatic change (e.g. López-Gómez and Arche 1997). The sedimentary record and stratigraphy of continental fluvial sediments in rift-basins provide an opportunity to assess their role (Gawthorpe and Leeder 2000), although it is often difficult to isolate their relative impact.

The Permo-Triassic succession of the Central High Atlas Basin of Morocco offers exceptional exposure of continental fluvial-dominated sediments deposited in a rift basin (Figure 1a). Within this section, the Oukaimeden Sandstone Formation is dominated by the deposition of ephemeral and perennial braided fluvial systems (Fabuel-

* Correspondence to: C. Baudon or J. Redfern, SEAES, The University of Manchester, Oxford Road, Williamson Building, Manchester M13 9PL, UK E-mails: catherine.baudon@gmail.com; jonathan.redfern@manchester.ac.uk 


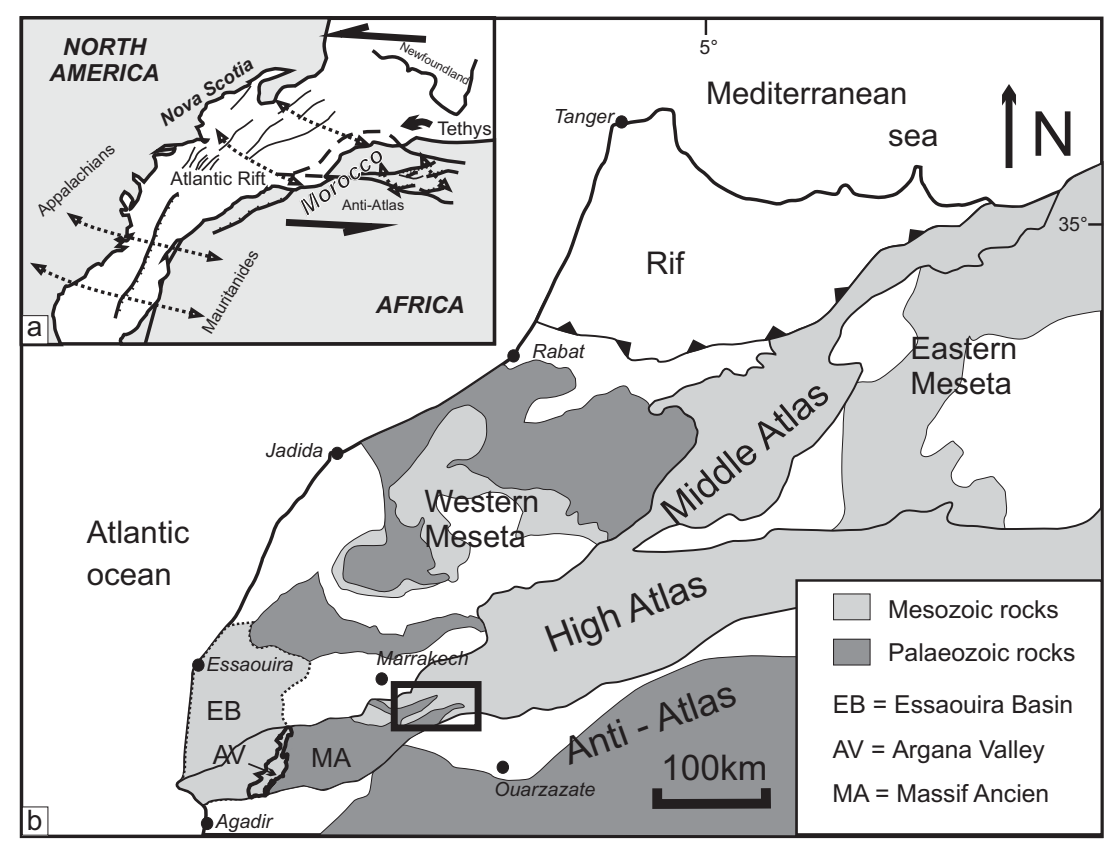

Figure 1. (a) Reconstructed palaeogeography showing the location of Morocco during Triassic time and the principal extensional stress patterns (modified after Laville and Pique 1991), (b) Present-day structure map of Morocco (modified after Ellouz et al. 2003 and Ait Brahim et al. 2002). The location of the study area is indicated by the rectangle.

Perez et al. 2009) and offers a potential analogue for prolific Triassic sandstone reservoirs within similar rift settings along the Atlantic Margin and across North Africa. These rift basins formed in response to extensional tectonics associated with the break-up of Pangea, attributed to the opening of the Atlantic Ocean and Neo-Tethys Sea (e.g. Van Houten 1977; Petit and Beauchamp 1986). The Central High Atlas Basin is an ENE elongated riftbasin bounded by deep-rooted normal faults whose syn-depositional activity created the necessary subsidence for the accumulation of a thick succession $(>5 \mathrm{~km})$ of Upper Triassic continental sediments. The sequence unconformably overlies Precambrian and Palaeozoic rocks. A second population of faults trending NNE offset the basin, and these are characterized by having smaller dimensions and throws. Reactivation and inversion of the riftgraben due to Alpine compression led to uplift of the High Atlas, resulting in subsequent erosion and exposure of the Upper Triassic continental rocks. The Oukaimeden Sandstone Formation has recently been the subject of a study providing details on the sedimentology and architectural style (Fabuel-Perez et al. 2009), and these outcrops in the Oukaimeden-Ourika Valley provide excellent exposures to investigate the relative roles played by tectonics and climate on continental sediment deposition.

Previous studies of the High Atlas Triassic rifts have mainly focused on the large-scale structural evolution (e.g. Petit and Beauchamp 1986; Beauchamp 1988) or detailed sedimentology and stratigraphy of specific formations (e.g. Benaouiss et al. 1996; Mader 2005; Fabuel-Perez et al. 2009). This paper presents a study of the structural evolution of the Oukaimeden-Ourika Basin and integrates local basin kinematics to the regional geodynamic context of western Morocco during the Triassic. This study also evaluates the potential interplay of structural and climatic controls on the deposition of the Triassic Oukaimeden Sandstone Formation continental sediments.

\section{GEOLOGICAL SETTING}

The study area is located in the Oukaimeden-Ourika Valley, situated in the Central High Atlas Basin (Figure 1b). The High Atlas is one of the main structural domains in Morocco, an ENE oriented mountain range comprising 
mainly Mesozoic rocks, bounded by the Precambrian and Palaeozoic Anti-Atlas to the south and Massif Ancient in the east, the latter separating the Central High Atlas Basin from the Essaouira Basin.

The present-day geometry of the Central High Atlas Basin comprises a number of ENE-WSW trending narrow rift basins and reflects a complex history that can be divided in four major phases (Figure 2) (Laville et al. 2004). The pre-rift phase is characterised by compression related to the Hercynian Orogeny and assembly of Pangaea. Late Palaeozoic crustal-thinning associated with the early break-up of Pangaea resulted in extension. Early syn-rift NEENE trending normal faults developed, possibly reactivating older Hercynian structures, producing a horst and graben geometry (Laville et al. 2004, Laville and Pique 1991; Pique and Laville 1996). In the late Triassic, the High Atlas developed as an elongated NE to ENE striking rift-basin and the geodynamic evolution of this main syn-rift phase has been explained by the dual influence of Atlantic rifting to the west and formation of the Tethys Sea to the north (Figure 1a) (Ellouz et al. 2003; El Harfi et al. 2006). Syn-tectonic fill of the basins (Biron and Courtinat 1982; Beauchamp 1988) with siliciclastic continental sediments (El Arabi et al. 2003) was followed by the extrusion of widespread basalt flows attributed to the Central Atlantic Magmatic Province (CAMP) event (Olsen et al. 2003).

Post-rift thermal relaxation, linked to the failed Atlasic rift (Laville et al. 2004), and a relative sea-level rise led to the deposition of carbonate platforms of Jurassic to Cretaceous age (Pique et al. 2002). In the late Cretaceous, rotation of the African Plate and convergence with the European/Asian Plate induced the onset of a compressional phase associated with the Alpine Orogeny (Ellouz et al. 2003). This compression led to the reactivation and inversion of Triassic extensional structures into reverse faults associated with major uplift and minor folding of the Triassic sequences and subsequent erosion (Mattis 1977; Manspeizer et al. 1978; Pique et al. 2002; Ellouz et al. 2003; El Harfi et al. 2006).

\section{STRATIGRAPHY AND DEPOSITIONAL ENVIRONMENTS}

The Permo-Triassic series in the Central High Atlas have been divided into six formations (Figure 3), based on lithology and the identification of major discontinuities (Mattis 1977; Biron and Courtinat 1982; Benaouiss et al. 1996). Due to a lack of an angular unconformity between Permian and Triassic rocks, and limited dating of this dominantly continental succession (Beauchamp 1988), the age of the series is only poorly constrained by available palaeontological (e.g. Dutuit 1976; Jalil and Janvier 2005), palynological (Cousminer and Manspeizer 1976; Olsen et al. 2000) and radiometric data (Van Houten 1977).

Formations F1 (Anrar Conglomerate) and F2 (Cham-El-Houa Siltstone) comprise mainly conglomerates and sandstones and are dated as Permian in age (Dutuit 1976; Van Houten 1977). Permian sediments are present to the north of the study area, north of the Ourika-Zar Anticline, although they are absent from the Oukaimeden-Ourika Valley (Figure 4). Early or middle Triassic sediments have not been recorded to date in the Central High Atlas Basin (Cousminer and Manspeizer 1976). Formations F3 to F6 have been dated as late Triassic in age (Cousminer and Manspeizer 1976; Biron and Courtinat 1982). In the study area they rest with a major angular unconformity onto Palaeozoic basement rocks, which were strongly deformed by the Hercynian Orogeny.

Formation F3, named the Basal Conglomerate or locally the Conglomerat de Timalizene (Mattis 1977), is ca. $45 \mathrm{~m}$ thick and directly overlies Palaeozoic basement rocks in the Oukaimeden-Ourika Valley. This formation is characterized by massive conglomerates, composed of sub-angular poorly sorted cobbles characteristic of alluvial fan deposits, interbedded with sandstone and mudstone, interpreted as distal alluvial fan deposits, grading laterally into sandstones interpreted to be braided fluvial facies (Mattis 1977; Petit and Beauchamp 1986).

The Ramutcho Siltstone Formation (F4) is up to $175 \mathrm{~m}$ thick (Figure 3) and consists of siltstones and isolated lenses of fine- to medium-grained sandstones exhibiting trough cross-bedding in which bioturbation has been recorded (Mattis 1977). These are interpreted as fluvial channel and floodplain deposits (Mattis 1977; Fabuel-Perez et al. in press), although evidence for a tidal-flat environment has also been suggested (Biron and Courtinat 1982; Petit and Beauchamp 1986).

The Oukaimeden Sandstone Formation (F5) overlies Formation F4 with a sharp contact in the northern part of the study area and a more gradational contact to the south, (Fabuel-Perez et al. 2009), and can be subdivided into three 


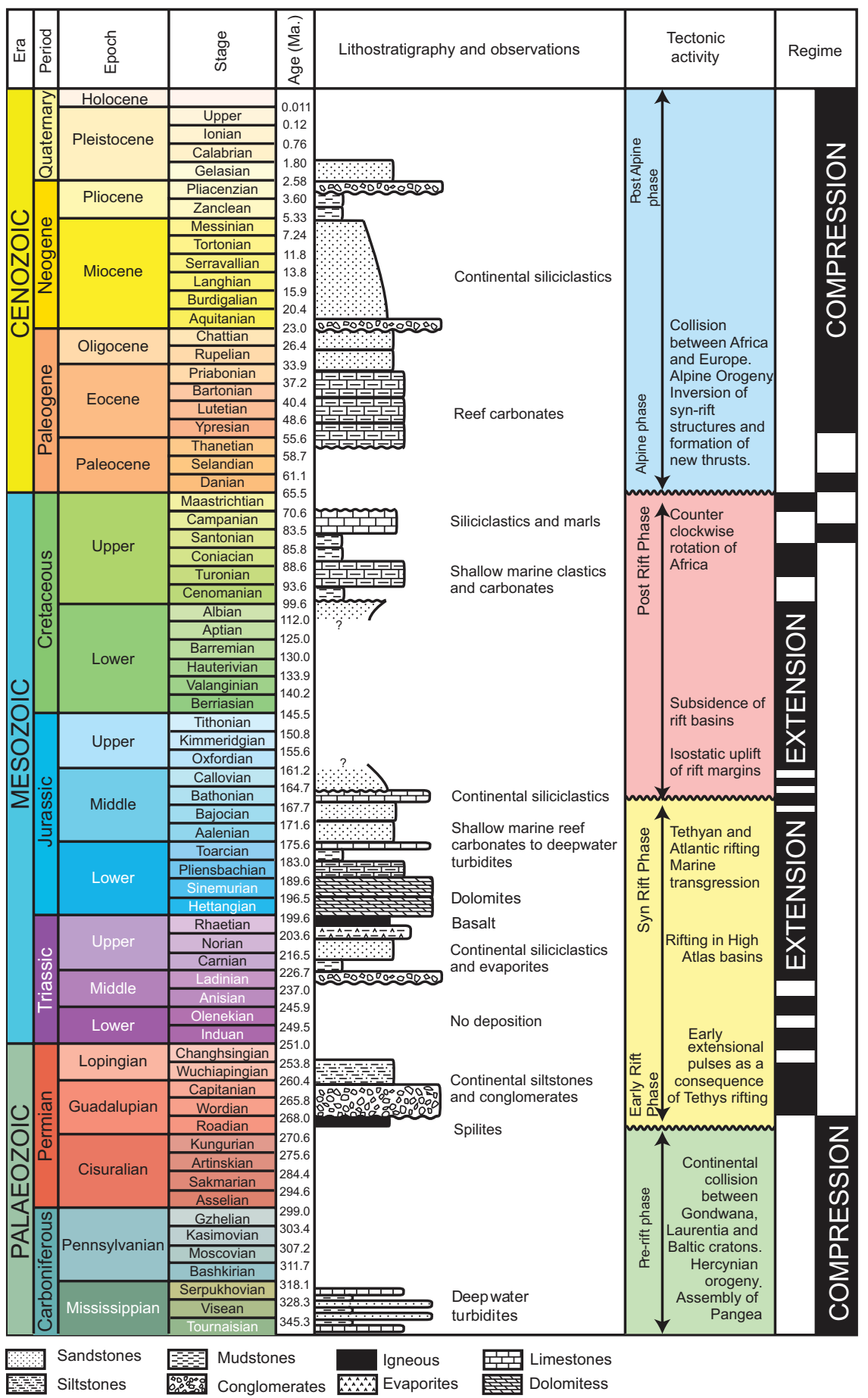

Figure 2. Composite lithostratigraphic and tectonic chart for the Central High Atlas basin, showing the main tectonic events (data complied from Beauchaamp et al. 1996, Le Roy et al. 1998, Beauchamp et al. 1999. Timescale from Gradstein et al. 2004. 


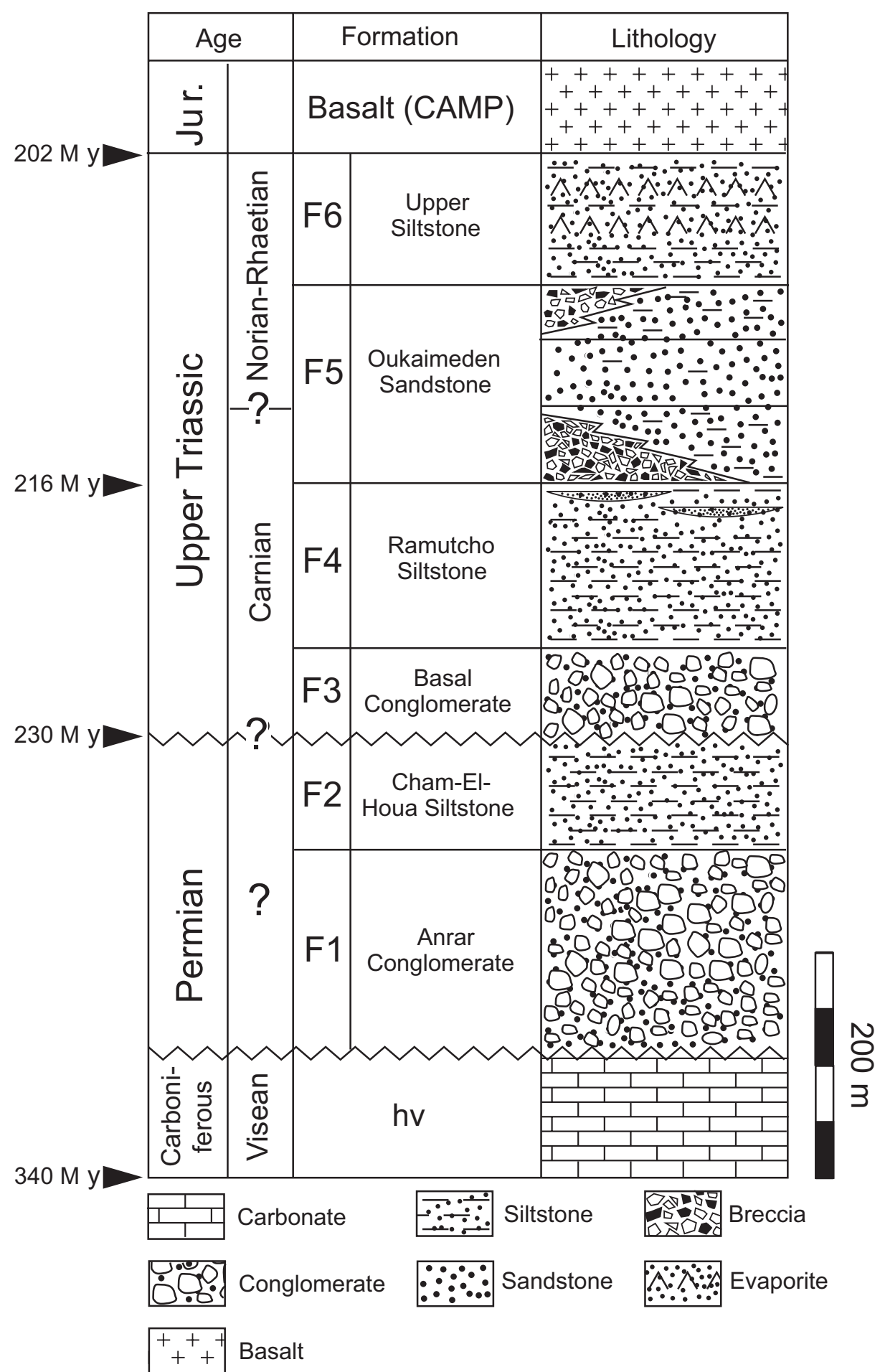

Figure 3. Lithostratigraphic summary log for the Oukaimeden-Ourika Valley (dates are based on Cousminer and Manspeizer 1976; Dutuit 1976; Van Houten 1977; Olsen et al. 2000 and thicknesses are modified from Mattis 1977 and Benaouiss et al. 1996). CAMP=Central Atlantic Magmatic Province; hv =haute Visean (upper Visean); Jur = Jurassic 


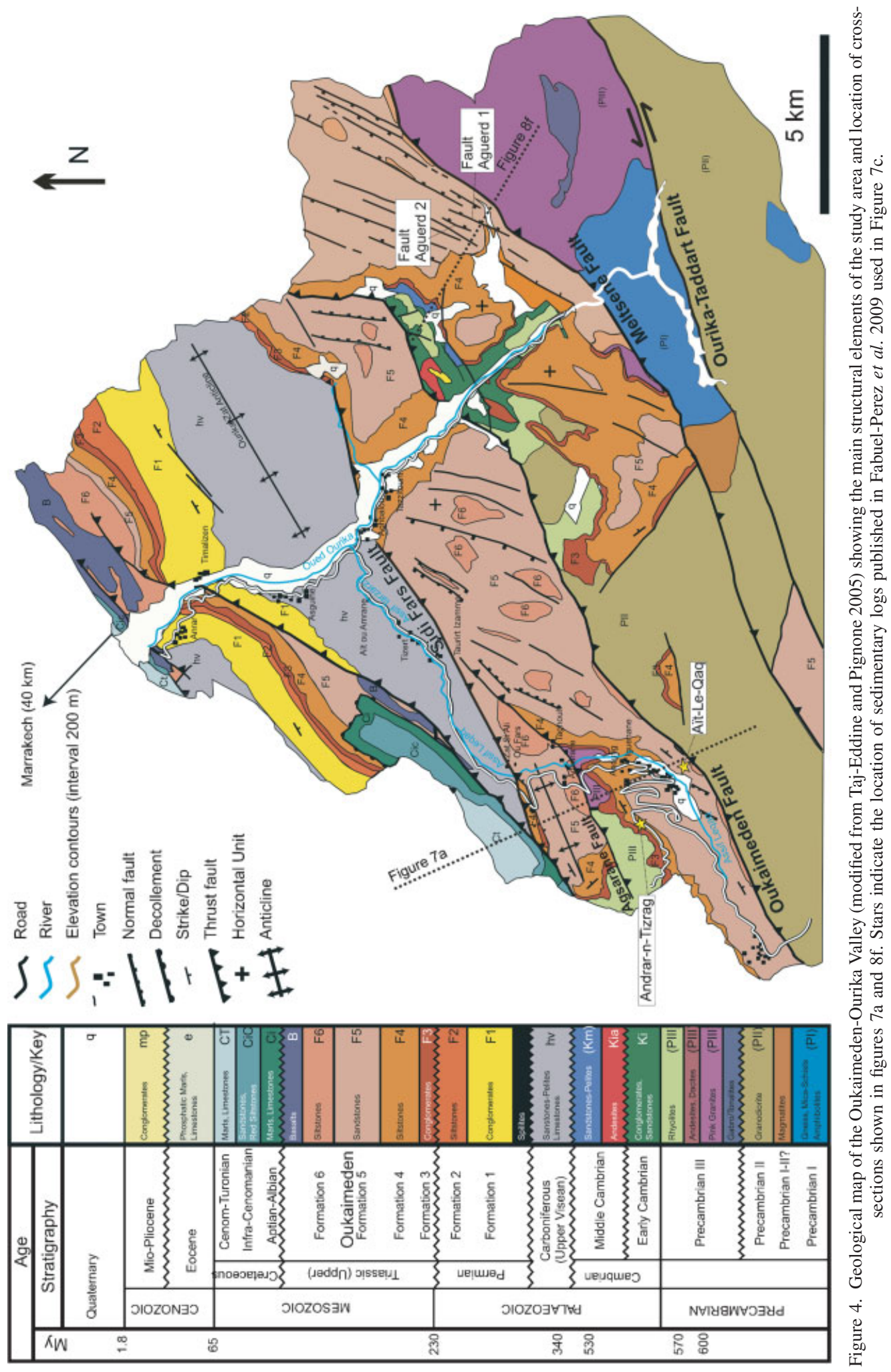

Copyright (C) 2009 John Wiley \& Sons, Ltd.

Geol. J. 44: 677-691 (2009) DOI: $10.1002 / \mathrm{gj}$ 


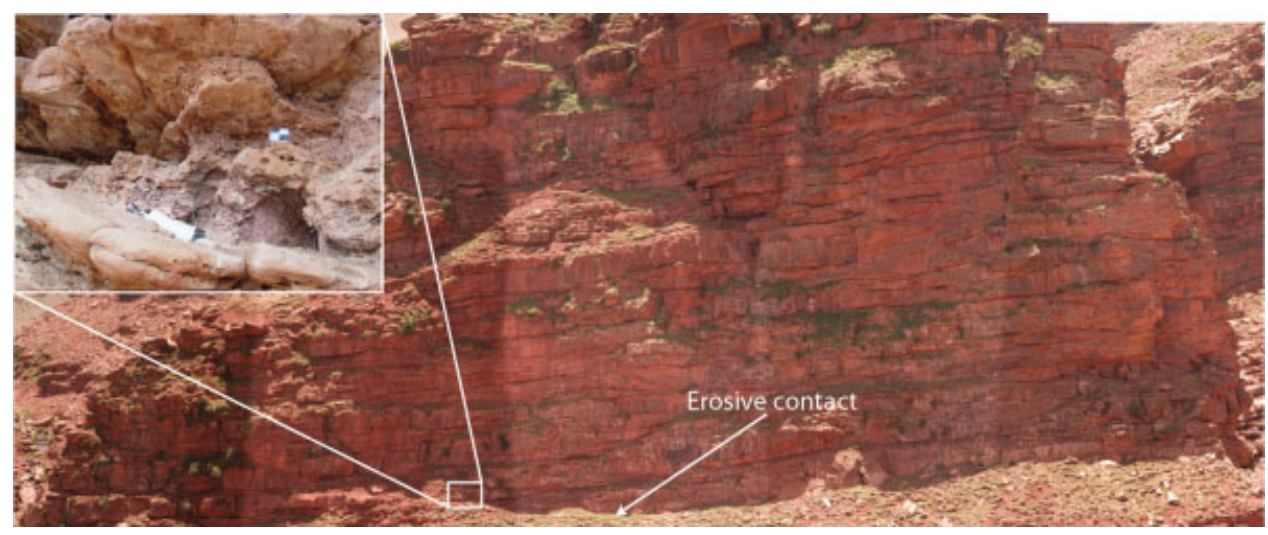

Figure 5. Photograph of the erosive contact at the base of the middle Oukaimeden, with detail showing the base of an erosive channel.

members based on architectural style. The lower member is $30-110 \mathrm{~m}$ thick and consists of conglomerate and coarse-grained sandstones at the base, interpreted as alluvial fan deposits alternating with fluvial channel and bar deposits, as well as laterally continuous floodplain mudstones. This is overlain by the middle member with an erosional basal contact (Figure 5). The middle member comprises $c a .50-80 \mathrm{~m}$ of vertically stacked sandstones, deposited as fluvial channel bodies intercalated with lenticular bars, and less common isolated overbank mudstone units. The first occurrence of aeolian dune sandstones characterizes the upper member, which comprises an alternation of alluvial fan deposits and fluvial sandstone channel and sand-bar deposits (Fabuel-Perez et al. 2009). Although earlier workers suggested a fluvio-deltaic environment (Biron and Courtinat 1982; Petit and Beauchamp 1986; Benaouiss et al. 1996), a revised sedimentological interpretation proposes deposition in ephemeral to perennial braided fluvial systems characterized by a preferred palaeocurrent orientation towards the NE (FabuelPerez et al. 2009). Intervals of alluvial fan conglomerates alternate with the fluvial sandstone facies on the northern margin of the study area. The alluvial fans have a preferred palaeocurrent towards the SE (Figure 6).

Formation F6 (Upper Siltstone) is up to $75 \mathrm{~m}$ thick, and rests unconformably on Formation F5. It is characterized by bioturbated red siltstones and mudstones with occasional evaporites and calcretes (Biron and Courtinat 1982; Beauchamp 1988; Benaouiss et al. 1996). Interpretations of the environment of deposition vary from alluvial plain (Mattis 1977) to marine-lagoon with localized continental playa (Biron and Courtinat 1982). Basaltic lava flows overlying Formation F6 are 5 to $30 \mathrm{~m}$ thick and attributed to the CAMP event, defining the contact with the overlying Jurassic deposits (Olsen et al. 2003).

\section{STRUCTURAL EVOLUTION}

The Oukaimeden-Ourika Valley is characterized, like many Triassic basins in the High Atlas of Morocco, by two main fault populations (Figure 4). The dominant structural trend is oriented NE-SW to ENE-WSW and shorter NNE-SSW striking faults form the second fault set. The main characteristics and kinematics of these two main sets of faults are analyzed in this section, followed by an investigation of the reactivation and inversion of the main structures due to later compression.

\subsection{NE-SW to ENE-WSW striking faults}

Triassic rocks in the Oukaimeden-Ourika Basin are bounded by NE-SW to ENE-WSW striking faults, which represent the main structural trend of the basin (Figure 7). These faults are tens of kilometres in length and are characterized by throw values of hundreds of metres, (Figures 4 and 5a). They dip towards the SE or SSE and the present-day geometry of the basin shows that they have been subsequently reactivated and inverted. Prior to 


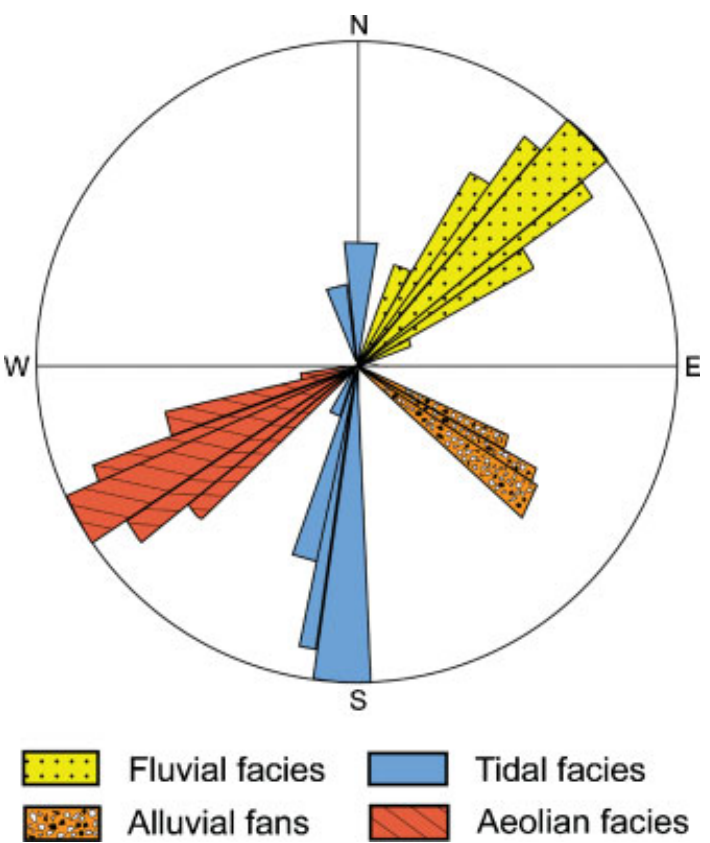

Figure 6. Palaeocurrent measurements from the Oukamaiden Formation, showing the orientation of fluvial facies sourced from the SW, and alluvial fans sourced from the Sidi Fars footwall to the NW, with palaeocurrent data oriented perpendicular to the fluvial facies. Sample size: 300 measurements in the Oukaimeden-Ourika Basin.

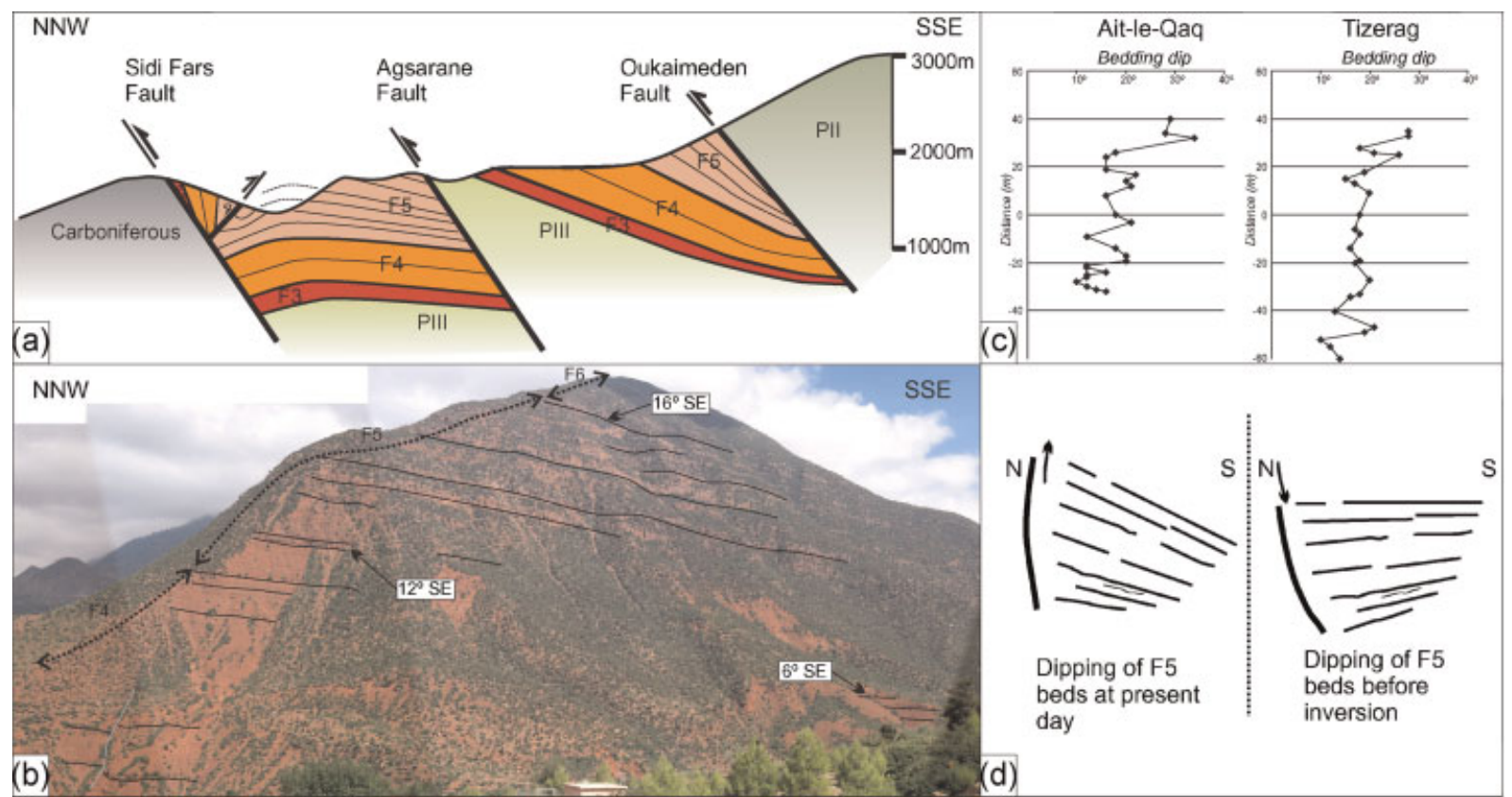

Figure 7. (a) Structural cross-section across the Oukaimeden-Ourika Basin perpendicular to the ENE striking faults. PII and PIII are Precambrian rocks. Location of cross-section is indicated on Figure 4. (b) Photo showing stratigraphic thickening of the Triassic interval towards the Sidi Fars Fault, located in the NNW. (c) variation of dip values of F5 bedding measured in the upper and middle F5 members. Both graphs show an upward increase of dip values. (d) schematic cartoons illustrating the present-day dip of F5 bedding and restored dips before inversion. 
inversion, the basin is interpreted to have comprised a series of half-grabens, where Triassic sediments were deposited in the southern hanging-wall blocks of each NE to ENE trending fault. Initially, the Triassic proximity of the Aguerd Fault were likely to have been deposited over a wider area, as shown by the presence of small outcrops of Triassic rocks located just a few kilometres south of the Oukaimeden Fault on the uplifted block of Precambrian basement. Present-day Triassic sediments are preserved in what were the deeper areas of the basin, and due to later inversion and consequent erosion, they are mostly absent on the southern hanging walls, now forming the inverted Precambrian blocks (Figure 4).

The Sidi-Fars Fault is a large NE striking fault (Figures 4 and 7) and has been interpreted as the main fault defining the basin margin and controlling the main depocentre for Triassic sedimentation in the study area. Analysis of this fault provides an opportunity to study the relationships between stratigraphy and tectonics. A structural cross-section, drawn across the Oukaimeden-Ourika Basin and perpendicular to the faults, shows variations in sedimentary thicknesses of the Triassic succession towards the main faults (Figure 7a). The average thickness of the Triassic interval is greater in the hanging-wall of Sidi-Fars Fault than in the footwall of Oukaimeden Fault. This is corroborated by the differences in thicknesses observed in measured sections. The lower member of the Oukaimeden Sandstone Formation (F5) is $c a .73 \mathrm{~m}$ thick to the south at Ait-Le-Qaq, whereas it is up to $c a .126 \mathrm{~m}$ thick in the north, closer to the fault in Andrar-n-Tizrag (cf. Fabuel-Perez et al. 2009). The general increase in thickness and divergent geometry of Triassic beds towards the Sidi-Fars Fault can be seen on the NW-SE crosssection across the Ourika Valley (Figure 7b). Beds dip at $6^{\circ}$ towards the SE in F4, progressively increasing to $12^{\circ}$ at the base of F5, up to $16^{\circ}$ at the top of F5. Variation in thicknesses of the Triassic series is also observed in a direction parallel to the fault plane, with thinning observed towards the NE lateral tip of Sidi-Fars Fault. This is typical of syn-sedimentary faulting, and many studies describe thickening in the depocentres in the central part of growth faults, and thinning towards lateral fault tip terminations (e.g. Childs et al. 2003; Leppard and Gawthorpe 2006).

This interpretation of the Sidi-Fars Fault as a growth fault is also supported by progressive changes in dip values observed from several logged sections of the Oukaimeden Sandstone Formation across the basin, all of which show a progressive increase in dip towards the top of the series. Two examples are illustrated in representative logs of the Ait-le-Qaq and Andrar-n-Tizrag sections (Figure 7c). After restoration of the basin geometry to its position before inversion, by rotating the bedding in the upper part of F5 to the initial horizontal position of deposition, dip values can be observed to progressively increase towards the base of the formation, as would be expected with growth into a syn-sedimentary fault (Figure 7c) (Edwards 1976).

Discrete breccia units comprising centimetre to metre-scale beds of sub-angular to angular carbonate clasts in a coarse-grained sandstone matrix, intercalated with the mud and sandstone units in the Lower and Middle Oukaimeden Formation (Fabuel-Perez et al. 2009), are interpreted to record deposition from alluvial fans that were sourced from erosion following footwall uplift of the Sidi-Fars Fault. Together, these elements provide evidence to interpret the NE to ENE striking faults, and the Sidi-Fars Fault in particular, as syn-sedimentary and controlling Upper Triassic deposition.

The nature of the basal tip of the NE to ENE faults is difficult to determine as no sub-surface data are available in this area. The dips of the fault planes are very high $\left(>70^{\circ}\right)$, although Alpine compression has probably modified and possibly steepened the dip of the faults. No syn-sedimentary roll-over or progressive discordance of the strata close to the fault plane has been observed in the hanging-wall blocks of the faults. Their sub-horizontal fault trace is roughly straight and no curvature can be observed in map view that would be typical of a fault geometry detaching at depth (Figure 4). Together these observations would suggest that the faults do not detach within the Triassic and that the NE to ENE faults are deep-rooted into the basement. It is possible that the major faults reactivated preexisting Hercynian structures, as has been previously suggested for major structures with a similar orientation in Triassic basins in Morocco (Laville and Pique 1991; El Arabi et al. 2003).

\subsection{NNE faults}

The basin is also offset by smaller normal faults characterized by a NNE-SSW (to NE-SW) orientation and dipping towards the SE and NW (Figure 4). These faults range from a few metres up to $7 \mathrm{~km}$ in length and offset late Triassic 
sediments with throw values ranging from tens to hundreds of metres. Some of these faults show evidence of reactivation and inversion in response to the later compressional phase. Two representative NNE faults are described in detail.

The Aguerd 1 Fault is a NNE-SSW striking fault offsetting the Triassic succession in close proximity to the large ENE striking Meltsene Fault (Figure 4). It is a normal fault dipping at $c a .50$ to $55^{\circ}$ towards the ESE. The Middle F5 sediments in the footwall and northwestern block of the fault are in contact with the top of F5 or F6 sediments in the hanging-wall (Figure 8a,b), so that the throw is estimated to be $c a .60 \mathrm{~m}$. Change of dip in the beds associated with a roll-over anticline have been observed in the hanging-wall block adjacent to the Aguerd 1 Fault on several cross-sectional views (Figure 8a,b). This geometry is typical of detaching growth faults, which accumulate sediments in the hanging-wall whilst being active at the surface, characterized by a basal-tip sliding on a detachment layer (e.g. Hamblin 1965).

The Aguerd 2 Fault is another example of a NNE striking normal fault, dipping towards the ESE and offsetting sediments of Formation F5. An outcrop perpendicular to the orientation of the fault shows stratigraphic thickening in the hanging-wall and progressive divergence of the strata towards the fault plane. Dip values increase from 024/ $28^{\circ} \mathrm{SE}$ at the base up to $026 / 42^{\circ} \mathrm{SE}$ towards the top of the series (Figure 8c). Restoring the bedding surface measurements to their horizontal position before Alpine inversion (Figure 8d) clearly shows the characteristic increase of throw with depth typical of syn-sedimentary faults. Although the fault plane is not observable at outcrop, many portions of the fault plane with hydroplastic slickensides were identified in fallen blocks and scree of the valley where the fault is located (Figure 8e).

These examples are representative of most of the smaller NNE to NE trending normal faults studied in the Oukaimeden-Ourika Valley. These faults show characteristics of syn-sedimentary faults such as increase of throw with depth, stratigraphic thickening in the hanging-wall blocks, associated with rapid change in dip values and hydroplastic slickensides on fault planes (Petit and Laville 1987). Dip-slip striations have been found on some of the fault planes oriented NE to NNE. In addition to these elements, slump deposits have been observed within Formation F6 sediments in the proximity of Aguerd 2 Fault (Figure 8d), suggesting syn-tectonic activity creating unstable conditions and movement of unconsolidated sediments. The high angle of divergence of bedding over a short distance suggests that not only are most of these faults syn-sedimentary, but also that they probably exhibit shallow detachment as illustrated on a structural cross-section of the Ourika Valley constructed in a NNW to SSE direction (Figure 8f).

\subsection{Reactivation and inversion}

The present-day geometry of the Central High Atlas reflects from the compressional Alpine phase of the MesoCenozoic tectonic event, expressed as reactivation and inversion of the main structures. The Oukaimeden Fault acted as a normal fault dipping towards the SE during Triassic time, but as a result of Alpine compression now displays a reverse geometry, juxtaposing Precambrian rocks in contact with Triassic sediments. The present-day throw on the Oukaimeden thrust fault is estimated to be at least $2000 \mathrm{~m}$, calculated from the structural cross-section (Figure 7a). The Meltsene Fault has also been inverted, but exhibits a more modest throw, probably because it underwent increased strike-slip movement compared to the Oukaimeden Fault.

The Sidi-Fars Fault displays good evidence of Alpine reactivation and inversion. It is characterized by a fault plane with a throw of up to $c a$. $2500 \mathrm{~m}$ that splays into two branches in the eastern part of the basin. The southern branch contains a small antithetic fault with associated tight drag folds along the fault zone (Figure 7a), which is characterized by breccia deposits. Rotation of the Triassic beds between the two fault splays forms a pop-up structure, interpreted to have been formed during the Alpine compressional phase. The original divergence of the strata due to syn-tectonic deposition was accentuated by high compressional strains within the pop-up structure.

Not all NNE faults were reactivated during the compressional phase, and reactivated faults show a variable amount of inversion. This degree of reactivation is attributed to the orientation of the structures with respect to the compressional strain (e.g. White et al. 1986), the dimension of faults and basal tip geometries (e.g. Baudon and Cartwright 2008). 

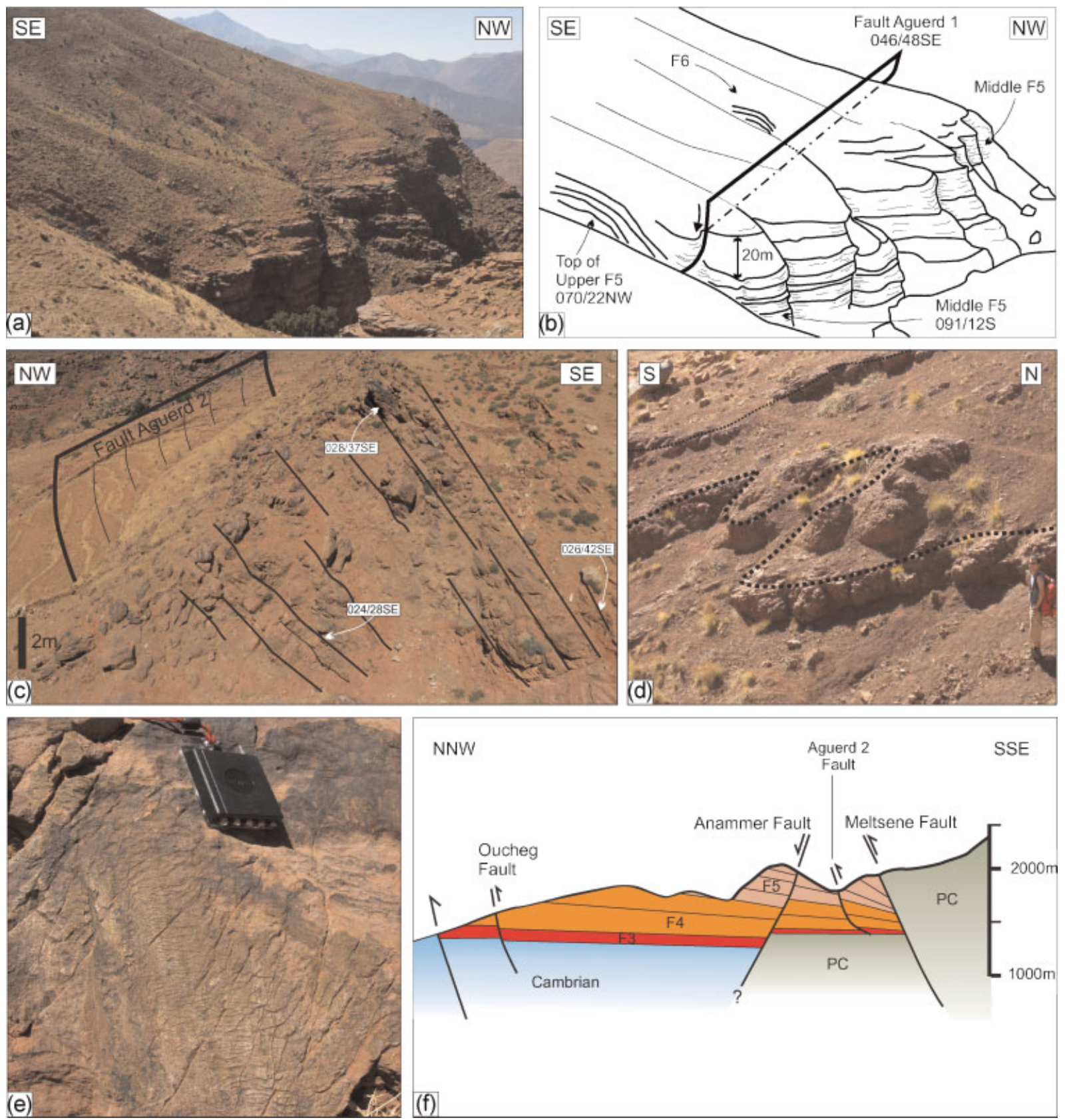

Figure 8. (a) Photograph showing the Aguerd 1 Fault (see b for scale) and (b) interpretation sketch showing roll-over of top of T5 sediments in the hanging-wall in contact with sediments of the Middle F5 (c) Photograph of the Aguerd 2 Fault showing stratigraphic thickening in the hanging-wall block. Rapid changes in dip are illustrated by T5 bedding (d) Slump observed within T6 sediments $200 \mathrm{~m}$ west of Aguerd 2 Fault (note person for scale). (e) Fault plane found in the valley offset by Aguerd 2 Fault showing hydroplastic slickensides (f) Structural cross-section across the Ourika Basin showing the bedding relationships to NE striking faults (see location on Figure 4). PC $=$ Precambrian 


\section{DISCUSSION}

Deposition of the Permo-Triassic succession in the Central High Atlas has been influenced by the structural evolution of the area. This section summarizes the structural evolution of the basin observed in the OukaimedenOurika Valley with respect to the geodynamic context of Morocco during the Triassic period. Climatic conditions are also interpreted to have varied during deposition of the late Triassic. The relative controls of the tectonics versus climate on sediment deposition are also discussed, focusing on the period of deposition of the Oukaimeden Sandstone Formation (F5).

\subsection{Structural evolution and the geodynamic setting during the late Triassic}

Most previously published models for the formation and evolution of the Triassic basins in Morocco suggest opening by pull-apart deformation along NNE-SSW striking normal faults, bounded by large ENE trending leftlateral strike-slip faults which had a normal component (Laville and Petit 1984; Beauchamp 1988). On a larger scale, two main phases of extension have been proposed, the first N-S, followed by a second in a NW-SE direction (Laville and Petit 1984; Medina 1991). In the Oukaimeden Valley NE to ENE striking faults produced a series of half-grabens during late Triassic deposition. However, we see no evidence from field observations to suggest two major phases of extension, switching from N-S to NW-SE in the study area. The geometry and infill of the Oukaimeden Valley can be explained by continuous or episodic extension in a NW-SE direction during the late Triassic. This direction of extension is illustrated by the near dip-slip striations on NE to NNE striking faults associated with left-lateral movement of ENE trending structures with a strong normal component. An earlier pulse of extension, oriented in a N-S direction (e.g. Petit and Beauchamp 1986; Medina 1991) could be recorded further north of the study area, where Permian sediments were deposited and preserved. However, in the Oukaimeden Valley, no Permian sediments have been deposited, suggesting that either only the later period of extension affected the study area, or the record of the Permian extensional phase was removed by erosion prior to the late Triassic.

Several studies conducted in similar Triassic basins in the High Atlas of Morocco, such as the Ec Cour Basin, show structural trends that are similar to those described from the Oukaimeden-Ourika Basin. It has been suggested that the Ec Cour Basin opened with pure extensional strain on two main fault sets oriented NE and NNE, which were probably inherited from pre-existing Hercynian structures (El Arabi et al. 2003). We have not seen any evidence of the influence of deep-rooted structures on the NE to NNE striking faults in the Oukaimeden-Ourika Basin. Detachment at the basal tip of the growth faults is observed to be consistently oriented in a similar direction, which suggests that the evolution of these structures did not involve reactivation of older structural features. This conclusion is in agreement with other authors who suggest that the NNE oriented faults in the Ec Cour Basin are not basement related structures (Beauchamp 1988).

\subsection{Structural controls on sediment deposition}

The major ENE faults controlled the geometry and dimensions of the Central High Atlas basins. No Permian sediments have been recorded in the Oukaimeden-Ourika Valley, in contrast to further north or in the Argana Valley to the southwest (Jalil and Janvier 2005). This absence can either be explained by erosion or a lack of deposition of Permian deposits. Deposition of Permian sediments followed by complete erosion seems unlikely, as no trace of Permian sediments has been recorded anywhere in the Oukaimeden Valley, whereas several hundred metres of Permian sediments are still exposed only a few kilometres north of the Sidi-Fars Fault. A lack of deposition is more likely and suggests that in Oukaimeden, primary activity along the ENE faults was only initiated in the late Triassic (or reactivation of the pre-existing faults). This resulted in deposition of the basal Upper Triassic conglomerates (F3) across the whole basin, resting upon a major unconformity.

The contact between Formations F4 and F5 is sharp in the northern area of the basin, in proximity to the Sidi-Fars Fault and becomes progressively gradational in the southern part, near Ait-Le-Qaq. The base of Formation F5 is an erosive surface produced by a fluvial system, comprising amalgamated channels. This erosive surface is observed in the northern part of the basin close to the fault. Channels become less frequent and overbank deposits dominate the 
interval towards the south. These sedimentological observations, allied with the change from an erosional unconformity to a gradational contact progressively away from Sidi-Fars Fault, suggest that the main fluvial system ran parallel to the fault. The increase in proportion of fluvial channels close to the fault was controlled by increased accommodation and associated river capture related to movement on the Sidi-Fars Fault, the main controlling fault in the Oukaimeden Valley.

Angular breccias and coarse conglomerates have been identified in the Lower and Upper Oukaimeden Sandstone Formation, and these are interpreted to be characteristic of alluvial fan deposits. The preferred orientation of palaeocurrents on the alluvial fans is towards the SE (Figure 6), which is normal to the orientation of Sidi-Fars Fault, and the dominant river-systems, which flowed towards the NE-ENE, following an axial trend parallel to the strike of the basin (Fabuel-Perez et al. 2009). The clasts in the alluvial fan facies are mainly composed of carbonates and less commonly quartz, and have the same composition as Carboniferous rocks that crop out on the footwall block of the Sidi-Fars Fault. The alluvial fans are interpreted as being sourced from the erosion of Sidi-Fars faultscarp and uplifted footwall. As they prograded they probably forced the coeval axial rivers away from the fault plane, as observed in similar half-graben rift basins (e.g. Gawthorpe and Leeder 2000).

\subsection{Climatic influence on sediment deposition}

In addition to the demonstrated tectonic control on the architectural style of the late Triassic sediments, climatic variation also played an important role. The contact between the lower and middle members of the Oukaimeden Formation (F5) is marked by an extensive erosional surface, which is overlain by very coarse sandstone or conglomeratic deposits. A similar unconformity has been described in other Triassic basins along the Atlantic margins (Olsen et al. 2000; Arche and López-Gómez 2005; Mader 2005). It has been suggested by previous workers that this boundary is due to a regional tectonic event which led to the reactivation of major fault systems (Olsen et al. 2000), which increased relief and run-off, which produced the erosional surface and enhanced input of coarse-grained sediments into the basin.

However, no angular unconformity is observed at this horizon and this contact could also record a change in climatic conditions rather than a regional tectonic event. A rapid change to more humid conditions in an environment characterized by sparse vegetation, such as the Central High Atlas Basin in Triassic time (in the basin or hinterland), would result in higher precipitation and run-off, increased sediment supply, and input of coarser sediments into the basin (Mader 2005). This climatic control would also explain the change in depositional style from a dominance of ephemeral fluvial discharge in the lower member of the Oukaimeden Sandstone Formation to perennial conditions in the middle member (Fabuel-Perez et al. 2009). The contact between the Middle and Upper F5 members is characterized by a converse change from perennial to ephemeral depositional conditions, interpreted to record a return to a drier climate. The occurrence of aeolian facies in the Upper F5 described by Fabuel-Perez et al. (2009) also suggests a coeval change to more arid climatic conditions at this time, providing another control on facies and architectural style.

It is difficult to establish the relative importance of structural versus climatic control on the change of sedimentation between these two members, as it probably results from a complex interplay between the two factors. Abandonment of the fluvial system could be due to reduction in the accommodation and controlled by cessation of movement on the NE to ENE basin bounding fault.

\section{CONCLUSIONS}

The Oukaimeden-OurikaValley contains two sets of faults: large NE to ENE striking faults bounding the basin and smaller NE to NNE oriented faults offsetting the Triassic succession. Evidence of syn-sedimentary movement of both sets of faults have been recognized, such as stratigraphic thickening across the faults and progressive divergence of strata towards the main fault planes, associated with progressive downward increase in bedding dip (Figures 5 and 6). The NE to ENE faults are interpreted to be potentially re-activated, deep seated pre-existing 
Hercynian structures, and these define the geographical extent of the basin. The NNE trending smaller faults formed synchronously with the reactivated ENE syn-sedimentary faults. They exhibit a typical growth fault geometry with basal tip detachment and indicate the direction of extension during late Triassic time. As a result of compression, all the NE to ENE faults were inverted during the late Alpine Orogeny. The NNE fault population shows evidence of variable reactivation.

Evidence of both structural and climatic controls on the deposition, thickness and architectural style of Triassic sediments has been recognized in this study. Structural control defines the geometry and dimension of the sedimentary basin, delimited by the location and the amount of throw along the main basin-bounding faults. The Sidi-Fars Fault is the main NE to ENE striking fault and it controlled the gross deposition of late Triassic sediments preserved today in the basin.

The contact between Formations F4 and F5 varies from being sharp in proximity to the fault plane to more gradational away from it, which, together with the associated facies changes, suggest a structural control on sediment deposition. The occurrence of alluvial fans in the lower and upper Oukaimeden units in the proximity of Sidi-Fars Fault is interpreted as characteristic of syn-sedimentary fault activity. The main channel belts are oriented sub-parallel to the controlling fault, and an increased proportion of sandstone is observed with proximity to the fault. The proportion of channel sandstones reduce away from the main faults, with a gradual reduction in net to gross, as overbank deposits predominate. This suggests that the location of the main fluvial system was controlled by the structure.

Recognition of aeolian facies in the upper part of the sequence, and evidence from the fluvial depositional facies and architecture suggests that the Triassic sequence was affected by a progressive climate change from more humid to more arid conditions. However, the change in architectural style between ephemeral to perennial conditions within the Oukaimeden Sandstone Formation (F5) is attributed to an interplay of both tectonic and climatic changes. A comparison of the late Triassic section preserved in the Oukaimeden-Ourika Valley with other coeval outcrops, such as those in the Argana Valley in the Western High Atlas, shows a similar climatic record, and further regional studies offer the potential to distinguish the relative roles of structural and climatic controls on fluvial deposition.

\section{ACKNOWLEDGEMENTS}

We wish to thank the sponsors of the North Africa Research Group (NARG): Hess, Anadarko, Conoco-Phillips, Repsol, RWE, Oxy, Wintershall, BG Group, Petrocanada, Pluspetrol, Maersk and Woodside for funding this research. This paper has benefited from thoughtful discussions with Laurent Petitpierre and Stéphane Bodin from NARG, University of Manchester. We acknowledge the National Office of Hydrocarbons and Mining (ONHYM) in Morocco for logistic and scientific support in the field, and in particular Majid Elouataoui.

\section{REFERENCES}

Arche A, López-Gómez J. 2005. Sudden changes in fluvial style across the Permian-Triassic boundary in the eastern Iberian Ranges. Spain: Analysis of possible causes. Palaeogeography, Palaeoclimatology, Palaeoecology 229(1-2): 104-126.

Ait Brahim L, Chotin P, Hinaj Sc, Abdelouafi A, El Adraoui A, Nakcha C, Dhont D, Charroud M, Sossey Alaoui F, Amrhar M, Bouaza A, Tabyaoui H, Chaouni A. 2002. Paleostress evolution in the Moroccan African margin from Triassic to Present. Tectonophysics 357(1-4): 187-205.

Baudon C, Cartwright J. 2008. The kinematics of reactivation of normal faults using high resolution throw mapping. Journal of Structural Geology 30(8): 1072-1084.

Beauchamp J. 1988. Triassic Sedimentation and Rifting in the High Atlas (Morocco). In: Triassic-Jurassic Rifting. Developments in Geotectonics, (edited by Manspeizer W). Elsevier, New York. 22: 477-497.

Beauchamp W, Barazangi M, Deminati A, El Algi M. 1996. Intracontinental rifting and inversion: Missour Basin and Atlas Mountains, Morocco. American Association of Petroleum Geologists Bulletin 80: 1459-1482.

Beauchamp W, Allmendinger RW, Barazangi M. 1999. Inversion tectonics and the evolution of the High Atlas Mountains, Morocco, based on a geological-geophysical transect. Tectonics 18(2): 163-184.

Benaouiss N, Courel L, Beauchamp J. 1996. Rift-controlled fluvial/tidal transitional series in the Oukaimeden Sandstones, High Atlas of Marrakesh (Morocco). Sedimentary Geology 107(1-2): 21-36. 
Biron P, Courtinat B. 1982. Contribution palynologique a la connaissance du Trias du Haut-Atlas de Marrakech, Maroc. Geobios 15(2): $231-235$. Childs C, Nicol A, Walsh JJ, Watterson J. 2003. The growth and propagation of synsedimentary faults. Journal of Structural Geology 25: 633648.

Cousminer HL, Manspeizer W. 1976. Triassic pollen date Moroccan High Atlas and the incipient rifting of Pangea as middle Carnian. Science 191(4230): 943-945.

Cowie PA, Gupta S, Dawers NH. 2000. Implications of fault array evolution for synrift depocentre development: insights from a numerical fault growth model. Basin Research 12(3-4): 241-261.

Dutuit JM. 1976. Découverte d'amphibiens lépospondyles dans la série inférieure de la Formation rouge d'Argana (Atlas occidental marocain). Comptes Rendus de l'Academie des Sciences, Paris 283: 1733-1734.

Edwards MB. 1976. Growth faults in upper Triassic deltaic sediments, Svalbard. American Association of Petroleum Geologists Bulletin 60(3): 341-355.

El Arabi EH, Ferrandini J, Essamoud R. 2003. Triassic stratigraphy and structural evolution of a rift basin: the Ec Cour basin, High atlas of Marrakech, Morocco. Journal of African Earth Sciences 36(1-2): 29-39.

El Harfi A, Guiraud M, Lang J. 2006. Deep-rooted "thick skinned" model for the High Atlas Mountains (Morocco). Implications for the structural inheritance of the southern Tethys passive margin. Journal of Structural Geology 28(11): 1958-1976.

Ellouz N, Patriat M, Gaulier JM, Bouatmani R, Sabounji S. 2003. From rifting to Alpine inversion: Mesozoic and Cenozoic subsidence history of some Moroccan basins. Sedimentary Geology 156(1-4): 185-212.

Fabuel-Perez I, Redfern J, Hodgetts D. 2009. Sedimentology of an intra-montane rift-controlled fluvial dominated succession: the Upper Triassic Oukaimeden Sandstone Formation, Central High Atlas, Morocco. Sedimentary Geology 218(1-4): $103-140$.

Gawthorpe RL, Leeder MR. 2000. Tectono-sedimentary evolution of active extensional basins. Basin Research 12(3-4): 195-218.

Gradstein FM, Ogg JG, Smith AG. 2004 A geological time scale. Cambridge University Press (Ed.): Cambridge, UK, 589 pp.

Hamblin WK. 1965. Origin of "reverse drag" on the downthrow side of normal faults. Geological Society of American Bulletin 76: 1145-1164.

Jalil NE, Janvier P. 2005. Les Pareiasaures (Amniota, Parareptilia) du Permien supérieur du Bassin d'Argana, Maroc. Geodiversitas 27: $35-132$.

Laville E, Petit J-P. 1984. Role of synsedimentary strike-slip faults in the formation of Moroccan Triassic basins. Geology 12: 424-427.

Laville E, Pique A. 1991. La distension crustale atlantique et atlasique au Maroc au début du Mésozoïque: le rejeu des structures hercyniennes. Bulletin de la Societe Géologique de France 162(6): 1161-1171.

Laville E, Pique A, Amrhar M, Charroud M. 2004. A restatement of the Mesozoic Atlasic Rifting (Morocco). Journal of African Earth Sciences 38(2): 145-153.

Le Roy P, Guillocheau F, Piqué A, Morabet AM. 1998. Subsidence of the Atlantic Moroccan margin during the Mesozoic. Canadian Journal of Earth Sciences 35: 476-493.

Le Roy P, Piqué A. 2001. Triassic-Liassic Western Moroccan synrift basins in relation to the Central Atlantic opening. Marine Geology 172(3-4): 359-381.

Leppard CW, Gawthorpe RL. 2006. Sedimentology of rift climax deep water systems; Lower Rudeis Formation, Hammam Faraun Fault Block, Suez Rift, Egypt. Sedimentary Geology 191(1-2): 67-87.

López-Gómez J, Arche A. 1997. The Upper Permian Boniches Conglomerates Formation: evolution from alluvial fan to fluvial system environments and accompanying tectonic and climatic controls in the southeast Iberian Ranges, central Spain. Sedimentary Geology 114(1-4): 267-294.

Mader NK. 2005. Sedimentology and sediment distribution of Upper Triassic fluvio-aeolian reservoirs on a regional scale (Central Algeria, SW Morocco, NE Canada): an integrated approach unravelling the influence of climate versus tectonics on reservoir architecture. PhD Thesis, University of Manchester

Manspeizer W, Puffer JH, Cousminer HL. 1978. Separation of Morocco and Eastern North America: A Triassic-Liassic Stratigraphic record. Geological Society of America Bulletin 89: 901-920.

Mattis AF. 1977. Nonmarine Triassic sedimentation, central High Atlas Mountains, Morocco. Journal of Sedimentary Research 47(1): 107-119.

Medina F. 1991. Superimposed extensional tectonics in the Argana Triassic formations (Morocco), related to the early rifting of the central Atlantic. Geological Magazine 128(5): 525-536.

Olsen PE, Kent DV, Et-Touhami M, Puffer JH. 2003. Cyclo-, magneto-, and bio-stratigraphic constraints on the duration of the CAMP event and its relationship to the Triassic-Jurassic boundary. In: The Central Atlantic Magmatic Province: Insights from Fragments of Pangea. Geophysical Monograph Series, (edited by) Hames W E, McHone J G, Renne P R, Ruppel C. Elsevier, New York. 136: 7-32.

Olsen PE, Kent DV, Fowell SJ, Schlische RW, Withjack MO, LeTourneau PM. 2000. Implications of a comparison of the stratigraphy and depositional environments of the Argana (Morocco) and Fundy (Nova Scotia, Canada) Permian-Jurassic basins. In: Le Permien et le Trias du Maroc: Acte de la premiere Reunion du Groupe Marocain du Permien et du Trias, Oujidi M, Touhami M (eds), Oujda: 165-183..

Petit J.-P, Beauchamp J. 1986. Synsedimentary faulting and palaeocurrent patterns in the Triassic sandstones of the High Atlas (Morocco). Sedimentology 33(6): 817-829.

Petit J.-P, Laville E. 1987. Morphology and microstructures of hydroplastic slickensides in sandstone. Geological Society, London, Special Publications 29(1): 107-121.

Pique A, Laville E. 1996. The central Atlantic rifting: Reactivation of Palaeozoic structures? Journal of Geodynamics 21(3): 235-255.

Pique A, Tricart P, Guiraud R, Laville E, Bouaziz S, Amrhar M, Ait Ouali R. 2002. The Mesozoic-Cenozoic Atlas belt (North Africa): an overview. Geodinamica Acta 15(3): 185-208.

Taj-Eddine K, Pignone R. 2005. L'Ourika: Haut Atlas-Haouz de Marrakech, Maroc. Un patrimoine geologique, biologique et culturel exceptionnel Florence: SELCA, scale 1:60.000, 1 sheet

Van Houten FB. 1977. Triassic-Liassic deposits of Morocco and Eastern North America: Comparison. American Association of Petroleum Geologists Bulletin 61(1): 79-99.

White NJ, Jackson JA, McKenzie DP. 1986. The relationship between the geometry of normal faults and that of the sedimentary layers in their hanging walls. Journal of Structural Geology 8(8): 897-909. 